\title{
THE 'STERNO-ETRUSSIA' GEOMAGNETIC EXCURSION AROUND 2700 BP AND CHANGES OF SOLAR ACTIVITY, COSMIC RAY INTENSITY, AND CLIMATE
}

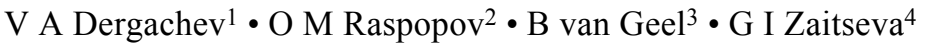 \\ ABSTRACT. The analysis of both paleo- and archeomagnetic data and magnetic properties of continental and marine sedi- \\ ments has shown that around 2700 BP, the geomagnetic Sterno-Etrussia excursion took place in 15 regions of the Northern \\ Hemisphere. The study of magnetic properties of sediments of the Barents, Baltic, and White Seas demonstrates that the dura- \\ tion of this excursion was not more than 200-300 yr.
}

Paleoclimatic data provide extensive evidence for a sharp global cooling around $2700 \mathrm{BP}$. The causes of natural climate variation are discussed. Changes of the galactic cosmic ray intensity may play a key role as the causal mechanism of climate change. Since the cosmic ray intensity (reflected by the cosmogenic isotope level in the earth's atmosphere) is modulated by the solar wind and by the terrestrial magnetic field, this may be an important mechanism for long-term solar climate variability. The Sterno-Etrussia excursion may have amplified the climate shift, which, in the first place, was the effect of a decline of solar activity. During excursions and inversions, the magnetic moment decreases, which leads to an increased intensity of cosmic rays penetrating the upper atmosphere. Global changes in the electromagnetic field of the earth result in sharp changes in the climate-determining factors in the atmosphere, such as temperatures, total pressure field, moisture circulation, intensity of air flows, and thunderstorm activity. In addition, significant changes in the ocean circulation patterns and temperature regimes of oceans will have taken place.

\section{INTRODUCTION}

High-resolution paleoclimatic records provide important information about climate change during the Holocene. Recent paleoclimatic studies have shown that significant natural climate variations occurred on centennial and millennial timescales (e.g. Dansgaard et al. 1993; Magny 1995, 2004; Bond et al. 1997; van Geel et al. 1999; Mann 2000; Johnsen et al. 2001; Esper et al. 2002). The climate can be affected by various types of external forcings which have different spatial and temporal scales of propagation in the climatic system. There is increasing evidence that many of the centennial and millennial climate changes are caused by solar forcing. The best-known example of a solar-climate effect is the cold period between AD 1645 and 1715, which coincides with the Maunder Minimum of solar activity (Eddy 1976).

Several extensive cold intervals occurred during the period between about AD 1450 and 1890 which is known as the Little Ice Age (LIA). Cold events during the LIA coincided with periods of relatively low solar activity. Human communities have always been sensitive to extremes of weather, and there is a great deal of information on weather conditions during the LIA in archived documents, particularly in England and western Europe, extending back to the early Middle Ages, as well as many centuries of records from China, India, and the Near East (Lamb 1995). Many paleoclimatic proxies confirmed that the LIA was a global phenomenon. During the Holocene, there were several similar periods of prolonged cold climatic conditions related to low solar activity (e.g. Dergachev and Chistyakov 1995).

Stratigraphical, paleobotanical, and archaeological evidence points to a change from a dry and warm to a more humid and cool climate in central and northwestern Europe at the boundary from Suboreal

\footnotetext{
${ }^{1}$ Ioffe Physico-Technical Institute, St. Petersburg, Russia. Corresponding author. Email: v.dergachev@pop.ioffe.rssi.ru. ${ }^{2}$ St. Petersburg Branch of IZMIRAN, St. Petersburg, Russia.

${ }^{3}$ Institute for Biodiversity and Ecosystem Dynamics, University of Amsterdam, the Netherlands.

${ }^{4}$ The Institute for the History of Material Culture RAS, St. Petersburg, Russia.
} 
to Subatlantic, between 2800-2500 BP (e.g. van Geel et al. 1996). Van Geel et al. (1996, 1998a) also argue that the climatic change affected settlement and land-use activities of European societies. New high-resolution Holocene climatic records provide a more detailed interpretation of cultural shifts in the past. In a recent study, Tinner et al. (2003) compared paleobotanical human impact indicators with independent high-resolution paleoclimatic proxies (oxygen isotopes in ice cores from Greenland and dendroclimatological data) in order to show evidence of the response of prehistoric and historic European cultures to climatic change. The authors suggested that gaps of the archaeological record during 800-650 and 400-100 BC in western and central Europe may indicate climate-driven land-abandonment phases.

There are quite a number of papers describing and interpreting the earth's natural climatic processes on long and short timescales. However, the processes influencing natural climatic change are difficult to understand and to predict. As the Sun is the only effective source of heat reaching Earth, the primary factors causing both short- and long-term climatic changes on the earth's surface are the result of the physical nature of the Sun, and Earth's spatial relationship to the Sun on long-term intervals. As shown in some studies, plausible reasons for changing atmospheric circulation patterns can be changes in the solar activity (e.g. van Geel et al. 1999) or changes in the thermohaline circulation in oceans (e.g. Bond et al. 1997). Bond et al. (2001) suggest a close link between changes in solar activity and past climatic changes over the North Atlantic and Europe. Magny (1993a, 2004) and van Geel et al. $(1996,1998 a)$ argue that Holocene climatic changes affected settlement and landuse activities of prehistoric European societies.

Nevertheless, solar variability remains controversial as a source of climate change, since no causal physical mechanism linking changing solar activity and climate change has been established. From among the assumed factors and mechanisms, the variation of solar irradiance is the most obvious, but there is no direct evidence that the irradiance of the Sun is varying significantly on long timescales. The recent observation of correlations between the galactic cosmic ray intensity and the surface of the earth covered by low clouds (Svensmark and Friis-Christensen 1997) may provide an important clue. Their results demonstrate the high positive correlation of the galactic cosmic ray intensity and cloudiness during long-term cosmic ray modulation in the 11-yr solar activity cycle. An increase of the cosmic ray intensity may lead to an increase in global cloud cover after ionization in the atmosphere by cosmic rays, resulting in an increased aerosol formation and cloud nucleation. Thus, an increase in the global cloud cover may be caused by cooling of the earth during periods of low solar activity.

Since the galactic cosmic ray intensity is modulated by the solar wind, a galactic cosmic ray cloud link could provide a sufficiently amplifying mechanism for solar-climate variability. This would constitute an extra contribution to climate change, in addition to the direct contribution from irradiance changes. Along with solar modulation of the galactic cosmic ray intensity, fluctuations in the geomagnetic field strength are also a cause for variations of the galactic cosmic ray intensity. Earth's magnetic field undergoes a steady-state change and non-periodical short events due to reversals or excursions. The galactic cosmic ray intensity, and subsequently, the cosmogenic production rate in the earth's atmosphere, are increased when the geomagnetic field is less intense. There are a few reports about excursions recorded in lake deposits and marine sediments. The youngest excursion was recorded by Ransom (1973) and has been called the Sterno event (Noel and Tarling 1975) or Sterno-Etrussia event in Russian papers. In the Baltic Sea sediments, Kochegura (1992) observed large variations of the direction of the geomagnetic dipole around 2800 BP. Based on archeomagnetic data from Georgia (Caucasus), Burlatskaya and Chelidze (1990) found that the strength of the geomagnetic field was reduced by 2 to 2.5 times around $2800 \mathrm{BP}$. A reduction of the geomagnetic 
dipole moment would lead to a sharp increase of cosmic ray penetration into the middle and low latitude atmosphere, which would strongly increase the production of cosmogenic isotopes on a global scale. Ultimately, the increase of cosmic rays during the excursion could lead to increased cloud cover and precipitation. Dergachev et al. (2000) and Raspopov et al. (2000) showed that the examination of the combination of external factors (solar activity, cosmic ray enhancement, and fast changes of the geomagnetic field) may contribute to a better understanding of the climate and solar activity as the possible cause of major climatic changes, as well as of breaks in the development of material culture in the past.

The main aims of this study are the following: 1) to present new evidence for the climatic cooling event around $2700 \mathrm{BP}, 2$ ) to demonstrate the spatial extension of the Sterno-Etrussia excursion, and 3 ) to discuss the possible causal connection between galactic cosmic ray intensity and climate.

\section{A Quasi-Cyclical Occurrence of Changing Solar Activity, Cosmic Ray Intensity, and Climate}

On the basis of radiocarbon chronologies of mountain glaciers in North America and Europe, Denton and Karlen (1973) established a synchronous and regular millennial-scale pattern of climate variation during the Holocene. Even after $30 \mathrm{yr}$, the evidence for this long-term regular climate change has not been widely accepted. Based on measurements of soluble impurities in Greenland ice, O'Brien et al. (1995) demonstrated that the Holocene atmospheric circulation above the ice cap was punctuated by a series of millennial-scale cooling events. They established that these increases in soluble impurities probably occurred at times of lowered atmospheric temperatures. The most prominent shifts appeared to correspond with periods of glacial advances (Denton and Karlen 1973).

Bond et al. (1997) carried out detailed investigations of deep-sea sediments (ice-rafted debris: IRD) in the North Atlantic, and established that the North Atlantic's Holocene climate must have undergone a series of abrupt reorganizations, each one with sufficient impact to force concurrent increases in debris-bearing drift ice. Bond et al. showed that cool, ice-bearing waters from the North Atlantic advanced abruptly, synchronous with changes in the atmospheric circulation as recorded in Greenland ice. The IRD events exhibit a quasi-cyclic occurrence with a millennial-scale periodicity through the Holocene. The youngest peaks occurred during the Little Ice Age (LIA) period and about $2800 \mathrm{yr}$ ago. The LIA mode appears to have been the most recent cold phase in the series of millennial-scale cycles. The rafting icebergs are triggered simultaneously from many glaciers, so the driving mechanism must be a common climate forcing mechanism. It points to a trigger that caused air temperatures to drop and induce the release of ice over a large region. For the North Atlantic, the IRD data showed that there has been much more climate change during the Holocene than previously thought. Until recently, the origin of the millennial climate cycle was unknown. Orbital periodicities around the Sun are too long to cause millennial-scale climate cycles. Recent studies (e.g. by Vasiliev et al. [1997] and Vasiliev and Dergachev [2002]) showed that the large maxima of 2300-2400-yr periodicity in atmospheric ${ }^{14} \mathrm{C}$ concentrations may be caused by long-term decreases in solar activity and may be related to cooling climatic periods with Alpine glacier expansions (Denton and Karlen 1973; Rothlisberger 1986) and sharp changes of the Caspian Sea level (Karpychev 1994). The abrupt climate change around $2700 \mathrm{BP}$ is a major event in this series of cool intervals.

Bond et al. (2001) have shown that solar variability is highly correlated with the ice-rafted debris events during the Holocene. As shown in Figure 1a and b, there is good correlation with the galactic cosmic ray intensity $\left({ }^{14} \mathrm{C}\right.$ record in tree rings). The correlation includes the LIA, the most recent event, and the abrupt climate change around $2700 \mathrm{BP}$. This rather convincing evidence suggests that solar forcing has caused the long-term climatic cycle during the Holocene. The most pronounced maxima of glacier advance (Maisch et al. 1999) were synchronous with high amplitudes of long-term 
variations of ${ }^{14} \mathrm{C}$ rate production (Figure 1c). Magny $(1999,2004)$ has reconstructed the history of lake levels in the French Jura Mountains. Holocene lake-level fluctuations correlate well (Figure 1d) with the changing galactic cosmic ray intensity ( ${ }^{14} \mathrm{C}$ record). This implies that the Jura lake levels also correlate with the periods of increased ice-rafted debris in the North Atlantic (Renssen et al. 2000).
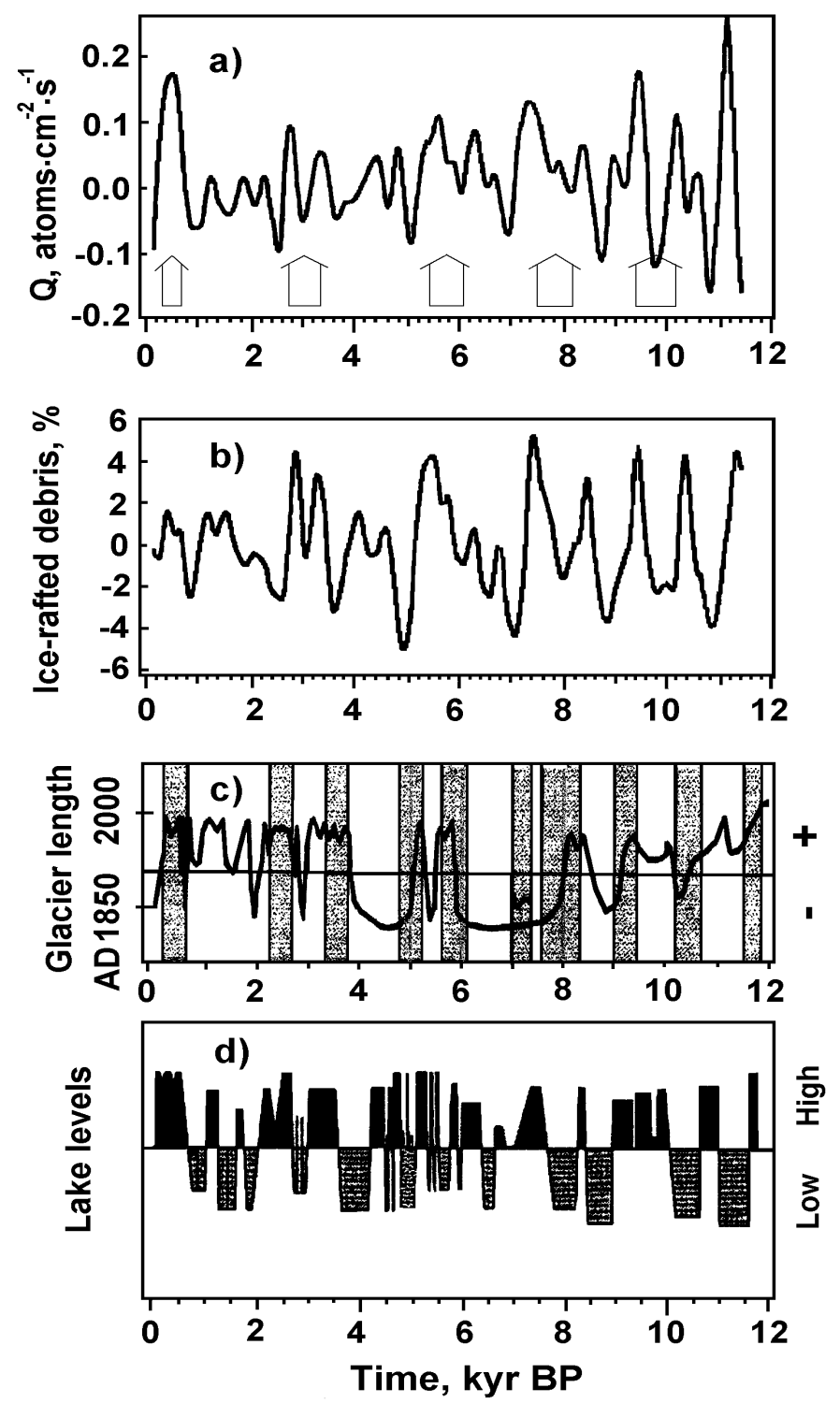

Figure 1 Comparison of (a) cosmic ray variability $\left(Q\right.$ is smoothed ${ }^{14} \mathrm{C}$ production rate from ${ }^{14} \mathrm{C}$ record of Stuiver et al. 1993); (b) combined ice-rafted debris in the North Atlantic (Bond et al. 2001); (c) estimated length variation of Swiss glaciers (Maisch et al. 1999); cold intervals are indicated by the shaded areas; (d) lake-level fluctuations in the French Jura Mountains (Magny 1999). The arrows show the extrema of the long-term changes of processes considered. 


\section{Manifestation of the Sterno-Etrussia Excursion}

Information about the youngest geomagnetic excursion was given by Ransom (1973), who mentioned the investigations by G Folgheraiter carried out in AD 1896 and 1899. While performing archeomagnetic studies of Attic and Etruscan vases in Greece and Italy (i.e. at latitudes between $\sim 35$ and $45^{\circ} \mathrm{N}$ and 10 to $25^{\circ} \mathrm{E}$ ), Folgheraiter discovered that the geomagnetic field had the inverse sign during the 8th century BC. The paleomagnetic anomalous changes in declination $D$ and inclination $j$ discovered by Folgheraiter were also observed by Nöel and Tarling (1975) in varved sediments in southern Sweden at around 860 BC. Nöel and Tarling called this excursion "Sterno." Sharp changes in inclination $j$ and declination $D$ (to $90^{\circ}$ ) dating to the 9th to 6th centuries $\mathrm{BC}$ were discovered by Nachasova et al. (1986) and Burlatskaya and Chelidze (1990) in archaeological material from settlements in the western Caucasus (Georgia), and this excursion was called "Etrussia." Nachasova et al. (1986) have shown that the duration of the changes in the geomagnetic field during this excursion was not more than about $100 \mathrm{yr}$.

Kochegura (1992) described this excursion based on magnetic properties of Baltic and Barents Sea sediments. In recent years, the behavior of the geomagnetic field during the Sterno-Etrussia excursion has been studied in detail by analyzing sediments in the Barents, Baltic, and White Seas. With different degrees of reliability, the excursion was revealed in 15 cores from the bottoms of these seas (Kochegura 1992; Kochegura et al. 1999). In 1998, during the 14th expedition of the research vessel Academician Sergei Vavilov, sediment cores were collected in the Barents Sea in order to study their chronostratigraphy and correlation. The Barents Sea is one of the key regions for the investigation of both post-Ice Age climatic history and ocean circulation patterns (Murdmaa and Ivanova 1999). The result obtained is the first information on paleomagnetic properties of Barents Sea sediments for the time interval of the last approximately 30,000 yr. One of the main results of the paleomagnetic investigations of Barents Sea sediments is the discovery of sharp changes of the geomagnetic field inclination $j$, which could be caused by the geomagnetic excursions SternoEtrussia (3000-2200 BP) and Solovki (7000-4500 BP). Figure 2 shows changes in magnetic properties of sediments in boreholes from the Barents Sea bottom. The sediments were dated by the ${ }^{14} \mathrm{C}$ method (Levitan et al. 1999). The core bottom is about $10,000 \mathrm{yr}$ old. The figure shows variations in inclination $j$ (Figure 2a, c), remanent magnetization $J_{n}$ (Figure 2b), and magnetic declination (Figure 2c). The geomagnetic Sterno-Etrussia excursion shows up as a sharp change of inclination in the time interval 2400-2200 BP. Along with this change, a considerable decrease in $J_{n}$ is observed against a background of increased $J_{n}$, which is the evidence for a decrease in the geomagnetic field during this period. The excursion duration is 100-200 yr. The investigation of magnetic susceptibility has shown that there are no specific mineralogical features during the period of geomagnetic excursion. This indicates that the changes in $j$ and $J_{n}$ described above are due to changes in geomagnetic field rather than caused by variations in the mineralogical composition of the sediments.

The behavior of the geomagnetic field intensity during the excursion is of fundamental importance for understanding the physical mechanism of climate change. For obtaining data on relative variations, series of experiments were worked out. Re-sedimentation of deposits from a number of cores in which the Sterno-Etrussia excursion had been observed was performed. The results showed that there was a decrease of the geomagnetic field intensity before and during the excursion (Kochegura 1992).

The example of the Sterno-Etrussia excursion discovery in sediments from the upper part of the $\mathrm{Ob}$ ' River basin (Siberia, Russia) is presented in Figure 3 (Gnibidenko et al. 2000). The changes of dec- 
a) b)

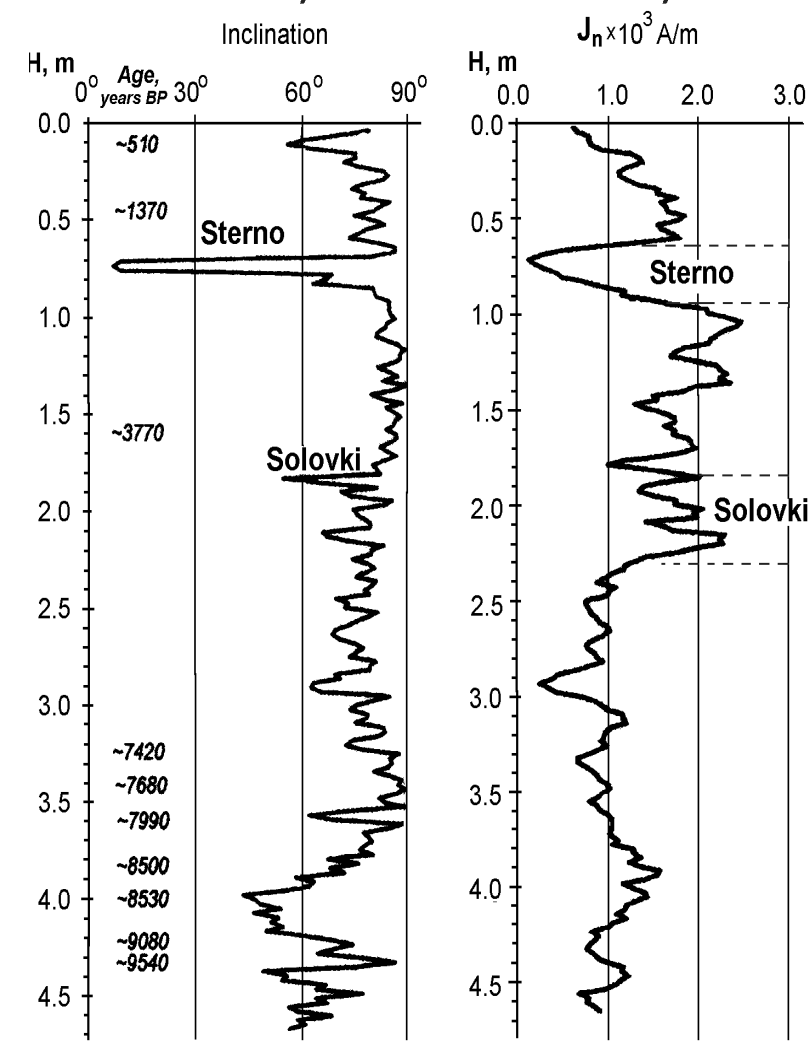

c)

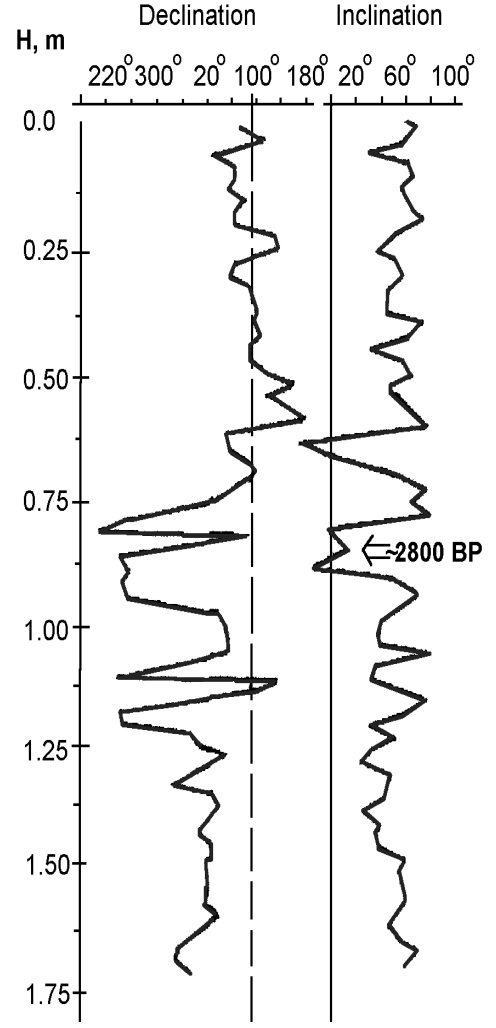

Figure 2 (a) Changes in inclination; (b) remanent magnetization $J_{n}$ in the Holocene sediments of the Barents Sea; and (c) in declination and inclination of the Baltic Sea sediments as a function of the depth (m).

lination $D$ during the excursion were $147^{\circ}$; the change of inclination $j$ was $60^{\circ}$. Here, it is also noted that the decrease of $J_{n}$ occurred under equal mean values of magnetic susceptibility $\kappa$ during the excursion. ${ }^{14} \mathrm{C}$ dating of the layer $(3185 \pm 50 \mathrm{BP})$ may serve as a confirmation of the excursion near this date. Wandering of the virtual geomagnetic pole during the period from 2700 to $2340 \mathrm{BP}$, inferred from studies of volcanic deposits of Mount St. Helens, Washington (Hangstrom et al. 2002), suggests that the excursion occurred during this time interval. The Sterno-Etrussia excursion, as recorded in different investigations, is presented in Table 1. The table reflects the area of paleomagnetic studies in the first place, and it would be premature to conclude about the extension of the Sterno-Etrussia excursion on a global scale. However, it is possible that the excursion was characteristic for the Northern Hemisphere.

Thus, studies of magnetic properties of sediments and archaeological materials during the geomagnetic Sterno-Etrussia excursion lead to the following conclusions. According to different results of dating, the excursion developed in the time interval 2800-2200 BP. Archaeological materials point to the 8th to 4th centuries BC. During the excursion, 1or 2 sharp deviations of inclination $j$ to 0 or negative values occurred, i.e., an abrupt displacement of the geomagnetic pole toward the Equator or its wandering to the Southern Hemisphere took place. The duration of this geomagnetic excursion was rather short, about 100-200 yr. 


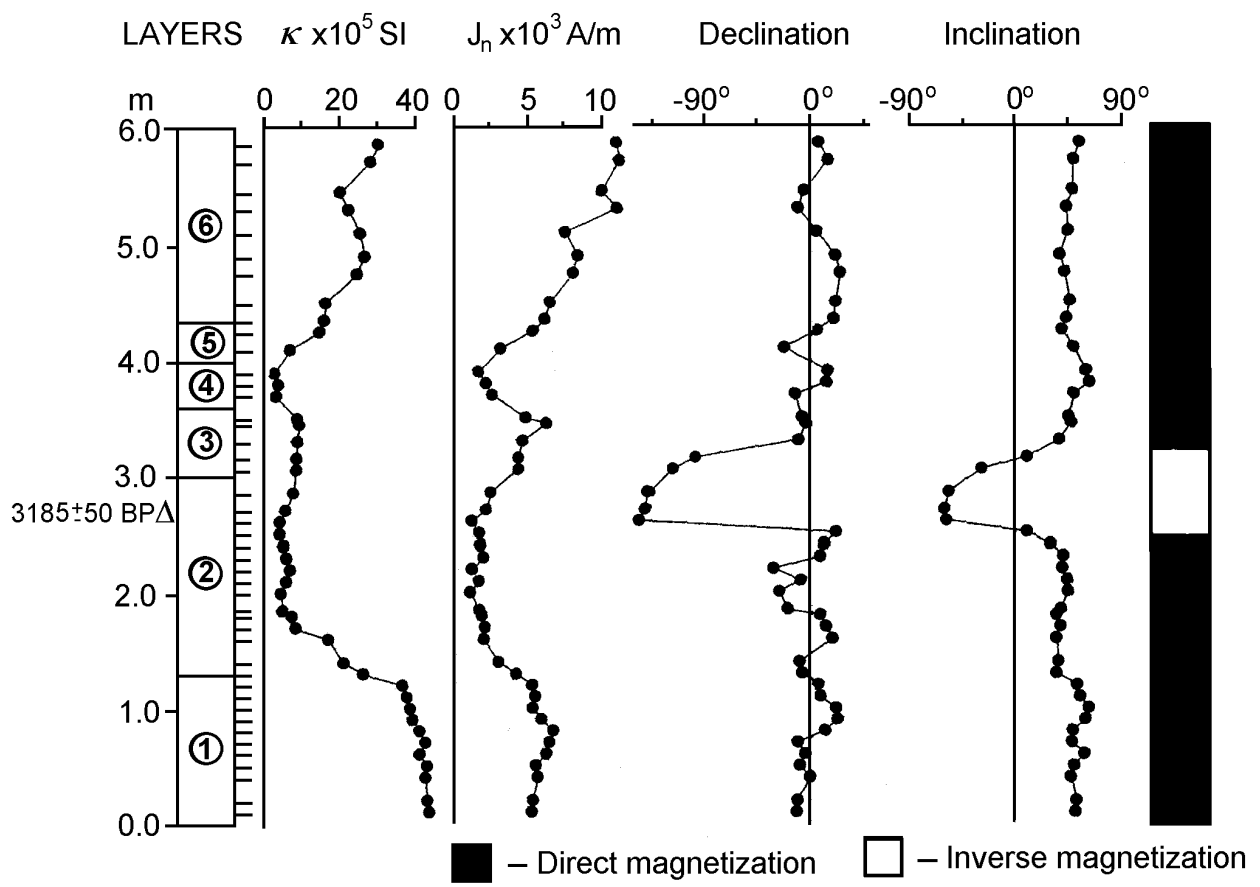

Figure 3 The magnetic characteristics of the Holocene continental sediments in upper part of Ob' River basin (Siberia, Russia): magnetic susceptibility $\kappa$, remanent magnetization $J_{n}$, declination, inclination, direct, and inverse magnetization (Gnibidenko et al. 2000).

Table 1 List of places where the excursion Sterno-Etrussia was determined.

\begin{tabular}{rlll}
\hline $\mathrm{Nr}$ & Place of the detection & Estimated age & References \\
\hline 1 & Creece, Italy & $800 \mathrm{BC}$ & Ransom 1973 \\
2 & Southern Sweden & $860 \mathrm{BC}$ & Nöel and Tarling 1975 \\
3 & Georgia & $800-700 \mathrm{BC}$ & Nachasova et al. 1986 \\
4 & Alaska & $3000 \mathrm{BP}$ & Morinaga et al. 1987 \\
5 & Yellow Sea & $3000-2800 \mathrm{BP}$ & Moqing et al. 1987 \\
6 & Northern Sweden & $2800-2550 \mathrm{BP}$ & Mörner and Sylvan 1989 \\
7 & Ukraine & $3000 \mathrm{BP}$ & Tretjak et al. 1989 \\
8 & Ural, Russia & $2500 \mathrm{BP}$ & Suleimanova et al. 1991 \\
9 & Turkmenistan & $<4500 \mathrm{BP}$ & Trubikhin et al. 1991 \\
10 & Northern coast of Caspian Sea, Russia & $3000-2500 \mathrm{BP}$ & Eremin et al. 1992 \\
11 & Baltic, Barents, White Seas & $3000-2800 \mathrm{BP}$ & Kochegura 1992 \\
12 & Karelia, Finland & $2500 \mathrm{BP}$ & Saarinen 1994 \\
13 & Siberia, Russia & $2875 \pm 75 \mathrm{BP}$ & Burakov et al. 1996 \\
14 & Siberia, Russia & $3185 \pm 50 \mathrm{BP}$ & Gnibedenko et al. 2000 \\
15 & Mount St. Helens, Washington, USA & $2700-2340 \mathrm{BP}$ & Hangstrom et al. 2002 \\
\hline
\end{tabular}

\section{Climatic Oscillations Around 2700 BP}

Van Geel et al. (1996, 1998a) and Speranza et al. (2002) studied the changing species composition of peat-forming mosses in European Holocene raised bog deposits. They found an abrupt shift at the onset of the sharp rise in the atmospheric ${ }^{14} \mathrm{C}$ concentration (decrease in solar activity) around $850 \mathrm{cal} \mathrm{BC}$, from mosses preferring relatively warm conditions to those preferring colder and wetter 
conditions. There is supporting archaeological evidence from the Netherlands. Bronze Age settlements which had been continuously inhabited for more than $1000 \mathrm{yr}$ were suddenly abandoned, presumably because the soil became waterlogged and peat growth started in areas which had been arable land. There is a substantial amount of geological and archaeological information showing that the climate changed abruptly around $2700 \mathrm{BP}$. We summarize a number of new studies about the abrupt climate change in different regions of the world during this period. We emphasize that the dating precision in some of the studies is rather low (large dating errors, poor sample resolution).

Barber and Langdon (2001) analyzed plant macrofossils in a peat deposit in northern England (Walton Moss) and compared the peatland proxy climate record with a temperature reconstruction based on chironomids in the sediments of a nearby lake. The main long climatic deteriorations identified from these proxy data occur between cal 2900-2830 BP, 2630-2590 BP, 1550-1400 BP; 500-400 BP, and 240-150 BP. Their results indicate that a major temperature decline occurred around $2600 \mathrm{cal}$ BP. Langdon et al. (2003) used a refined plant macrofossil record from Walton Moss and reconstructed the raised mire water tables during the Holocene. They established major climatic deteriorations at about 4410-3990 BP, 3170-2860 BP, and 2320-2040 BP.

Schilman and Bar-Matthews (2001) studied $\delta^{18} \mathrm{O}$ and $\delta^{13} \mathrm{C}$ in sediments from the southeastern Mediterranean, off Israel, and established humid phases in the time intervals of 3500-3000 and 1700-1000 BP, whereas relatively more arid conditions prevailed in the area between 3000 and $1700 \mathrm{BP}$ and during the last millennium.

Scott and Lee-Thorp (forthcoming) studied different climate proxy records across southern Africa and established marked isotope fluctuations in a cold air cave stalagmite. Climate variability as determined from the stalagmites shows periodic fluctuations in centennial and multi-decadal scales. All stalagmite sequences suggest cooling after $3200 \mathrm{BP}$, and also increasing development of C4 grasslands, peaking at $2000 \mathrm{BP}$.

Numerous investigations of postglacial climate in Canada were obtained from proxy records. The "neoglaciation" during 3000-2500 BP has been documented in the Canadian Rocky Mountains (Luckman et al. 1993). Wilson et al. (1997) showed that 3000-2500 BP was a period of downcutting in the Saskatchewan River system of western Canada, reflecting a cooler, moister climate. The proxy records from Harris Lake (Sauchyn and Sauchyn 1991) show that lower temperatures and plant productivity occurred (relatively low percentages of organic matter in the sediments) from 3000-2400 BP. This cool period coincided with a global phase of glacier growth, including the "mid-Neoglacial" advance in the Canadian Rocky Mountains at around 3000-2500 BP (Luckman et al. 1993).

In northern Iceland, the upper limit of tree/shrub birch (Betula pubescens) has been used by Wastl et al. (2001) as an indicator of summer temperatures. From the pollen and macrofossil investigations, it was established that there are 2 marked drops in the Betula pubescens curve of the VesturárdalurSkíðadalur area on the Tröllaskagi peninsula: from about 5000 BP to about $4500 \mathrm{BP}$ and before/ around $3000 \mathrm{BP}$. These variations can be compared to the record of Holocene glacier advances in northern Iceland. One of the glacier advances in the period around $3200-3000 \mathrm{BP}$, based on ${ }^{14} \mathrm{C}$ dating and tephrochronology, was established by Stötter et al. (1999).

The phenomenon El Niño has had severe consequences for the modern and (historically recorded) inhabitants of Peru, and El Niño events also influenced prehistoric cultural developments. Longterm proxy records for the El Niño-Southern Oscillation (ENSO) events indicate variable recurrence intervals and intensities. The Pacific coast of southern Ecuador and northern Peru is a core region of 
ENSO activity, and paleoclimate records there should reflect ENSO history. Peruvian coastal middens contain abundant marine mollusk valves that are proxy indicators for near-shore oceanic conditions $\left(\sim 7-20^{\circ} \mathrm{S}, 70-80^{\circ} \mathrm{W}\right)$. Analysis of midden remains from Peru (Sandweiss et al. 2002) suggests an increase in ENSO frequency between about 3200 and 2800 BP. This increase in El Niño frequency is correlated with the abandonment of monumental temples in the region after nearly 3 millennia of uninterrupted development and growth. By 2800 BP, the most warm temperaturesensitive mollusc assemblages (Choromytilus chorus, Mesodesma donacium) had disappeared from middens north of $9^{\circ} \mathrm{S}$, and over the following centuries, these species were largely replaced by others. Various climatic records support the increased ENSO after 3200 BP: water levels in Lake Titicaca, Peru-Bolivia (Abbott et al. 1997); an increase in lake levels in northern Chile (Betancourt et al. 2000); flood records from Quebrada Tacahuay (17 $48^{\prime} \mathrm{S}$; Keefer et al. 1998) and Quebrada de los Burros (18 $11^{\prime} \mathrm{S}$; Fontugne et al. 1999) on the far south coast of Peru, and others.

The Galapagos Islands, located within the core ENSO region, consistently experience positive precipitation and sea surface temperature (SST) anomalies during El Niño events, and possess a number of hypersaline lakes that experience reduced salinity during these periods. Galapagos lake sediment deposits are records of the history of salinity fluctuations, and thus provide a record of ENSO activity. Riedinger et al. (2002) performed lithostratigrahic and mineralogic analyses of sediments from the hypersaline Bainbridge Crater Lake, Galapagos Islands, and provided evidence of past El Niño frequency and intensity. They established that intensity of events increased at about $3000 \mathrm{BP}$ $(\sim 3100$ cal yr BP).

The Atlantic area demonstrates that marked variations in the distribution of water masses occurred repeatedly through the last $4500 \mathrm{yr}$ (Eiriksson et al. 2002). Of special interest is the exact timing of a marked drop in sea-surface temperature in the area, indicated by ice-rafting debris concentration, which occurred at $2980 \mathrm{cal} \mathrm{BP}$. This appears to predate most records of a general cooling event in NW Europe by a couple of centuries.

A number of periods with climate deterioration have been recorded in the Baltic Sea area and around the North Atlantic during the Holocene. It is possible that periods of increased wetness and reduced evapotranspiration may have increased the freshwater input into the Baltic Sea and decreased the salinity. Gustafsson and Westman (2002) used shore-level data and proxy data (mainly diatoms and shellfish) to evaluate phases of high and low salinity changes. They established a number of phases of decreased salinity, among which are phases coinciding with cold and possibly wet climatic phases in time intervals of 2900-2500 and 500-100 BP.

Estuarine and beach coastal marine deposits in New South Wales, Australia, which might point to an elevated Holocene sea level have been investigated by Bryant et al. (1992). From fossil corals found along the adjacent coast and also based on the elevation and orientation of the raised marine deposits, the authors drew the conclusion that the ocean temperature was higher around $2800 \mathrm{BP}$ by up to $2{ }^{\circ} \mathrm{C}$, and that sea levels from 6000 to $1500 \mathrm{BP}$ were over $1 \mathrm{~m}$ higher than at present. The marine deposits show little indication that they were deposited by storms, but the role of tsunami in their formation cannot be ignored.

Columnar stalagmites in caves of the Guadalupe Mountains, southwestern United States, during the late Holocene record a 4000-yr annually resolved climate history. The stalagmite record consistently provides a century and annually resolved history of climate (Polyak and Asmerom 2001). Thicker annual bands in 4 of the 5 stalagmites from $\sim 3000$ to 1700 BP indicate significantly greater effective annual moisture than at present. Intervals of increased moisture during the late Holocene in the southwestern United States are reported by numerous studies (e.g. McFadden and McAuliffe 1997; 
Wilkings and Currey 1999) supporting an interpretation favoring greater effective moisture during the late Holocene. A 200-yr period of thicker bands from 2800 to 2600 BP in these stalagmites reflects the wettest interval of the late Holocene for this region. This is synchronous with a reported abrupt change to cooler and wetter conditions in the temperate and boreal zones of Europe around 2650 BP (van Geel et al. 1998a). Also, the most notable increase in annual precipitation occurred from 440 to $290 \mathrm{BP}$ during a period of global cooling in the LIA. The period of the LIA was defined by a study of stalagmites from Madagascar as lasting from 425 to 230 BP (Brook et al. 1999) and was reported as beginning at $450 \mathrm{BP}$ on the basis of stalagmites from Nepal (Denniston et al. 2000).

Climate variability on the Yucatan Peninsula during the past $3500 \mathrm{yr}$ is reconstructed by Curtis et al. (1996) from the measurement of $\delta^{18} \mathrm{O}$ in monospecific ostracods and gastropods in lake sediments from Punta Laguna, Mexico. From $\sim 3310$ to $\sim 1785$ BP, low mean $\delta^{18} \mathrm{O}$ values indicate relatively wet conditions (i.e. low evaporation to precipitation ratio).

Tinner et al. (2003) performed palynological analysis of ${ }^{14} \mathrm{C}$-dated sediments from 4 lakes in Switzerland; the main attention was devoted to the period between $2300 \mathrm{BC}$ and AD 800. They also used a series of tree-ring density curves, glacier oscillations, paleobotanical timberline studies, ${ }^{14} \mathrm{C}$ content in tree rings, and compared these with the GRIP and GISP2 climatic record from Greenland. The conclusion was made that, although the general vegetation histories north and south of the Alps are different, climatic fluctuations in both areas are synchronous. Pronounced similarities between fluctuations of human impact indicators (pollen) and climate shifts suggest a common driving factor. Tinner et al. (2003) discussed possible driving factors (independent cultural developments and/ or climatic factors). Pollen data suggest that the reduction of agricultural activities (maximum of tree pollen, minimum of Cerealia and Plantago lanceolata pollen) north and south of the Alps was accompanied by natural afforestation. Most population discontinuities are considered to be closely related to climatic change.

In 2002 on the eastern side of Lake Bolshoy Turali along the Dagestan coast of the Caspian Sea, field work was carried out with a variety of techniques, including geomorphology, sedimentology, georadar, biostratigraphy, paleoecology, radiochronology, isotope geochemistry, landscape geochemistry, soil science, and process-based modeling. The selection of the site is based on the fact that Caspian Sea level high-stands are reflected in the highest levels reached by coastal barriers moving landwards during transgressions. The most reliable sea level curve for the Caspian Sea so far was given by Rychagov (1977). The first results of the new investigations were communicated during the workshop "Holocene Caspian Sea Level Change" at Delft University in the Netherlands in 2002. Attention was given to the reconstruction of Caspian paleoenvironmental conditions and transgressions. Kroonenberg et al. (2002) stressed that a considerable high-stand of the Caspian Sea around $2600 \mathrm{BP}$ corresponds with a period of low solar activity and high precipitation in the Volga drainage basin. A $<500 \mathrm{BP}$ high-stand coincides with the LIA. The data support the correspondence of Caspian high-stands with periods of global cooling.

Gracheva et al. (2002) presented a reconstruction of main regional stages of paleohydrological change and Holocene landscape evolution in the southern part of the Upper Volga Lowlands. At the Suboreal/Subatlantic transition (around $2600 \mathrm{BP}$ ), lake levels rose and caused abrupt flooding of soils which led to a collapse of the human economy in all lowland areas bordering the Klin-Dmitrov Heights (lower than $130 \mathrm{~m}$ asl). The abrupt hydrological change corresponds to the sudden disappearance of archaeological findings. 


\section{DISCUSSION}

Apparently, data reported in the preceding sections of this work have demonstrated that sharp climatic changes occurred in the time interval from $3000 \mathrm{BP}$ to $2500 \mathrm{BP}$. A drastic increase in the galactic cosmic ray (GCR) fluxes, well represented by an increase in the concentration of ${ }^{14} \mathrm{C}$ in tree rings, also took place during this time. Van Geel et al. (1998b, 1999) have drawn attention to this fact and have discussed possible mechanisms of the influence of cosmic rays on climate in the context of modulation of GCR fluxes by solar activity. In particular, they point out that an increase (decrease) of the GCR flux is able to result in attenuation (growth) of the global cloud cover and, therefore, in changes of the solar irradiance flux to low layers of the earth's atmosphere (Dmitriev and Lomakina 1977; Tinsley and Dean 1991; Pudovkin and Babushkina 1992a; Pudovkin and Raspopov 1992; Svensmark and Friis-Christensen 1997). Later, Pallé Bagó and Butler (2000) and Marsh and Svensmark (2000) have shown that variations of the GCR fluxes correlate in general with variations of the density of low cloudiness. Thus, increase of the GCR fluxes might be accompanied by cooling of the near-earth surface.

Tinsley and Dean (1991) have proposed that cosmic rays have an important influence on cloud microphysics. At altitudes from $\sim 3$ to $35 \mathrm{~km}$ in the earth atmosphere, cosmic rays are the only ionization source (natural radioactivity is an additional source of ionization below $\sim 3 \mathrm{~km}$ ). Experimental evidence of the plausible impact of galactic cosmic ray ionization on the precipitation efficiency of clouds was reported in Stozhkov et al. (1995). They demonstrate that the precipitation level is increased when the ionization level is increased in response to a higher flux of solar flare protons in the atmosphere. Using visual data from narrow range of latitudes $\left(60^{\circ} \mathrm{N}-64^{\circ} \mathrm{N}\right)$, which is consistent with global satellite observations, Pudovkin and Veretenenko (1995) have established a corresponding short-term decrease of cloudiness. They discovered that cloudiness and precipitation are reduced during the periods of high flux of cosmic rays in the atmosphere.

As another consequence of increase of the GCR flux, there might be a change in the ozone concentration in the atmosphere. Shumilov et al. (1992, 1995), Stephenson and Scourfield (1992), and Kodama et al. (1992) showed that solar proton events (SPE), which generate solar cosmic rays, may produce ozone mini-holes at high latitudes (decrease of the total ozone concentration is about 10 to $15 \%$ ) and they are accompanied by a decrease of temperature in the stratosphere (down to $-2.4^{\circ} \mathrm{C}$ ). Modeling experiments performed by Haigh $(1994,1996)$ suggest that such ozone depletion and stratospheric cooling could significantly affect the atmospheric circulation. Considering the period between 850 and $760 \mathrm{cal} \mathrm{BC}$, van Geel and Renssen (1998) have inferred from the results of Haigh that stratospheric cooling could have led to a weakening of stratospheric winds and displacement of the tropospheric jet streams toward the Equator. Moreover, they postulated that ultimately it might result in an increase of latitudinal extent of the Hadley Cells and in a weakening of the monsoons.

Thus, as a result of variability of the GCR fluxes, there might be not only changes of optical properties of the atmosphere connected with formation of the clouds cover and aerosol generation in the atmosphere, but there also might be changes in atmospheric circulation. This should substantially affect climatic parameters. The existence of influence of variations of the GCR fluxes on the atmospheric circulation was experimentally confirmed in Tinsley (1988), Pudovkin and Babushkina (1992b), and Cristoforou and Hameed (1997). Tinsley (1988) has shown that a shift in 3-5 degrees of the storm motion trajectory takes place in the Atlantic during solar activity maximum in comparison with solar activity minimum. Cristoforou and Hameed (1997) have obtained similar results for the northern part of the Pacific. 
Pudovkin and Babushkina (1992a) and Pudovkin and Raspopov (1992) have reported the results of an analysis of the impact of cosmic ray variation on zonal circulation in the troposphere during the development of strong magnetic storms. Veretenenko and Pudovkin (1993) have shown that decrease of the cosmic ray flux is accompanied by attenuation of the zonal circulation rate and increase of the cosmic ray flux is accompanied by growth of the zonal circulation rate.

Considering climate changes around $2700 \mathrm{BP}$, one can conclude that drastic increase of the GCR fluxes in this period, which might be connected with solar activity decrease or with influence of the geomagnetic Sterno-Etrussia excursion, should be accompanied by increased transfer of wet Atlantic air to the east-i.e., in Europe. This should result in the formation of cool climate and an increase in the precipitation amount in continental areas, which was actually observed. Note that similar climatic conditions were observed during the Maunder Minimum of solar activity.

Additionally, the papers of Haigh $(1994,1996)$ have one more important consequence. Displacement of the tropospheric jet stream toward the Equator under the influence of cosmic ray fluxes as well as a decrease of the latitudinal extent of the Hadley Cells means that response of the atmosphere to global perturbation should have a regional character, i.e., growth or weakening of external signal can take place at different latitudes and longitudes.

An ability of the atmospheric system to produce only regional response to a uniformly distributed external impact follows also from more general reasons. The system of atmosphere-ocean-continent, where the redistribution and transport of solar incoming energy takes place, is a non-linear system. Therefore, the spatial distribution of response to any external impact need not exactly follow the spatial distribution of the external forcing. It was also confirmed in model experiments.

A detailed statistical analysis of decadal and multidecadal patterns of the surface temperature response to solar irradiance variations based on analyses of the long-term surface temperature reconstructions during 1650-1850, including the period of the Maunder Minimum, is given in Waple et al. (2002). They estimated the response of surface temperature to solar irradiance variations (SRV) with a period of more than $40 \mathrm{yr}$ and for SRV with a period of 9-25 $\mathrm{yr}$. In the former case, the forcing factor was identified with the century type (Gleissberg) cyclicity of solar activity. The estimates revealed that in the case of Gleissberg cyclicity, the system of atmosphereocean-continent, which determines surface temperature, exhibits the highest sensitivity to solar signals with a lag of about $15 \mathrm{yr}$, which unambiguously suggest a non-linear character of the system. A response of surface temperatures to solar signal demonstrates a high spatial inhomogeneity. For instance, the regions of Scandinavia and Siberia are characterized by a strong positive response to increasing solar irradiance, while the region of western Greenland exhibits a negative response.

As to the impact of cosmic ray fluxes on climatic parameters, Waple et al. (2002) point out that climate response to the GCR fluxes which decrease from the pole to the Equator due to geomagnetic shielding will not follow the law of spatial distribution of GCR but show regional character. Because of differences in conditions of the cloudiness formation in various regions of the globe, the heterogeneity of the spatial atmospheric response to cosmic ray variations will be amplified. The analysis made previously of climatic events around $2700 \mathrm{BP}$ confirmed the idea of regional development of climatic response to external global forcing. Indeed, whereas cooling and precipitation growth occurred in Europe, warm and dry climate occurred on the west coast of Africa, pointing to the blocking of monsoons (Maley and Brenac 1998; Raspopov et al. 1998). Similar spatial structure of climatic processes was observed during the period of the Maunder Minimum of solar activity. 
As discussed earlier, van Geel et al. (1998a, 1999) have considered the impact of cosmic ray variations on climate around $2700 \mathrm{BP}$ in the context of solar activity changes. However, a possible influence of the Sterno-Etrussia excursion on the structure of GCR fluxes was not considered in that work. Therefore, let us consider the possible influence of structural change of the geomagnetic field and its configuration (shift of the geomagnetic pole to the Equator) during the excursion on structure of the GCR fluxes and, consequently, on climatic parameters. For this purpose, it is necessary to analyze changes of the magnitude of the geomagnetic dipole (or quadrupole), as well as change of the geomagnetic pole location, making use of paleo- and archaeomagnetic data.

Measurements of magnetic properties of 15 cores from sediments of the Barents, White, and Baltic Seas revealed sharp changes of inclination of the magnetic field at the same age in Holocene deposits. Paleomagnetic characteristics of Holocene-Pleistocene sediments were analyzed in sufficient detail for 9 cores taken from the Barents Sea during the expedition of the research vessel Academician Sergei Vavilov in 1998 (Murdmaa and Ivanova 1999; Guskova et al., forthcoming). Recently, the Sterno-Etrussia excursion was revealed with different degrees of reliability in 15 cores in the Holocene shelf sediments of the Baltic, White, and Barents Seas.

One of the main results of paleomagnetic investigations of the Barents Sea sediments is a discovery of sharp changes of the geomagnetic field inclination which might be caused by the geomagnetic excursions Sterno-Etrussia (2200-3000 BP) and Solovki (4500-7000 BP) (Figure 4a). Values of absolute ages for sediments obtained by ${ }^{14} \mathrm{C}$ dating are shown in Figure 4a. The sedimentation rate in the Barents Sea during the Holocene has been estimated making use of this dating, and is $45 \mathrm{~cm} /$ $1000 \mathrm{yr}$ (Levitan et al. 1999). It is significant that estimates of sedimentation rates can give an approximate timescale. The dating of anomalous values of inclination gave values of $\sim 2200 \mathrm{yr}$ and more than $4000 \mathrm{yr}$ (Figure 4a). Taking into account the obtained sedimentation rate, one can conclude that the inclination change at a depth of $70 \mathrm{~cm}$ is connected with this excursion. According to the sedimentation rate, its duration is about $200 \mathrm{yr}$. Using the paleomagnetic sample, one can derive 3 physical parameters: magnetic susceptibility $\kappa$, remanent magnetization $J_{n}$, and inclination $I$. The values of $\kappa$ are in a narrow range of -0.2 to $0.810^{-3} \mathrm{SI}$, which suggests the uniform distribution of magnetic minerals in sediments during the all the Holocene. Natural remanent magnetization $\left(J_{n}\right)$ strongly varies at a depth of $75 \mathrm{~cm}$. A considerable minimum is observed when $J_{n}$ decrease from 2.0 to $0.110^{-3} \mathrm{~A} / \mathrm{m}$. At the $90 \mathrm{~cm}$ depth, $J_{n}$ increases up to $2.510^{-3} \mathrm{~A} / \mathrm{m}$ and oscillates around the mean value of $1.510^{-3} \mathrm{~A} / \mathrm{m}$ up to $230 \mathrm{~cm}$. Inclination $I$ of $J_{n}$, averaged over 3 samples, changes sharply from 85 to $5^{\circ}$ at the $75 \mathrm{~cm}$ depth, and after the $350 \mathrm{~cm}$ depth, saw-tooth decreases of inclination are observed. It should be emphasized that the behavior of $J_{n}$ at the $70 \mathrm{~cm}$ depth (Figure 4a) may serve, perhaps, as indirect confirmation of the Sterno-Etrussia excursion at this depth, because $J_{n}$ decreases under uniform values $\kappa$ and thus gives information about a decrease of the geomagnetic field intensity during this period rather than about magnetization of minerals.

The existence of the Sterno-Etrussia excursion had been detected earlier in sediments of the Baltic Sea (Figure $4 \mathrm{~b}$ ). For this core, the change of inclination was $80^{\circ}$ and the relative change of declination (in the coordinates of drill tube) was $280^{\circ}$. Figure $4 \mathrm{c}$ (Gnibidenko et al. 2000) shows the SternoEtrussia excursion clearly seen in the Holocene continental sediments from the upper part of the $\mathrm{Ob}^{\text {' }}$ River basin (Siberia, Russia). The changes of declination during the excursion was $147^{\circ}$; the change of inclination was $60^{\circ}$. The decrease of remanent magnetization $J_{n}$, under the equal mean value of magnetic susceptibility $\kappa$ during the excursion, is also noticeable there. ${ }^{14} \mathrm{C}$ dating of this layer ( $3185 \pm 50 \mathrm{yr}$ ) can serve as a confirmation. The time differences of similar inclination variations, recorded at different locations, might be explained by the permanent westward drift of a non-dipole anomaly. 

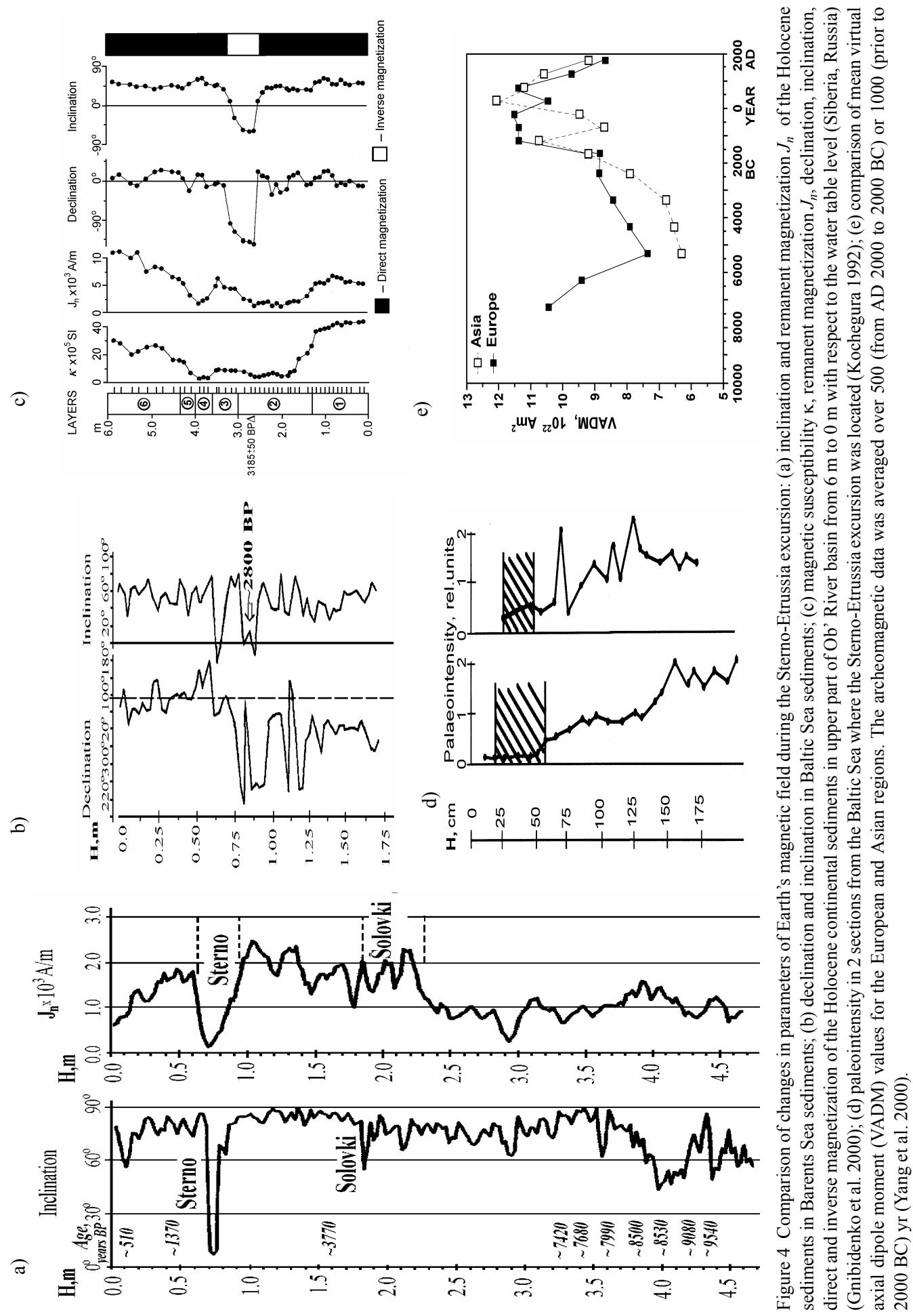
Data regarding the behavior of geomagnetic field intensity during the excursion are of great interest for understanding the physical mechanism responsible for the excursion. A series of measurements for a number of cores where the Sterno-Etrussia excursion might be recorded have been performed to obtain data on relative variations of sedimentation rate. The results demonstrate that in most cases, this rate decreases before and during the excursion. An example of such a decrease for 2 cores from the Baltic Sea is shown in Figure 4d, taken from Kochegura (1992) and modified in the present work. In sediments of the Baltic Sea, the change in inclination was accompanied by a 3 -fold reduction in the geomagnetic field intensity. According to the ${ }^{14} \mathrm{C}$ dating and sedimentation rate estimates, this event occurred between $2300 \mathrm{BP}$ and $3000 \mathrm{BP}$, and its duration is as short as 100-300 yr. On the basis of the age, one can associate the changes in the magnetic properties of sediments with the geomagnetic Sterno-Etrussia excursion.

There is also other evidence of a sudden drop of the geomagnetic field during the Sterno-Etrussia excursion. Studies of archaeological materials in Georgia (Caucasus) have shown that from the 9th to the 4th century BC, the geomagnetic field strength was approximately $40-60 \%$ higher than now (Nachasova and Burakov 2002). This result is consistent with the data of McElhinny and Senenayake (1982) and Yang et al. (2000). However, according to archeomagnetic data from Georgia, during fast changes of the geomagnetic field direction in this excursion, the field magnitude dropped below its present level (Burlatskaya and Chelidze 1987). Based on the virtual axial dipole moment (VADM) model and on archeointensity data, Yang et al.(2000) analyzed the secular variations of the geomagnetic field during the past 12,000 yr. Note that in archeomagnetic data, periods shorter than $1000 \mathrm{yr}$ are usually associated with changes of non-dipole field. Yang et al. (2000) averaged data over 500 and 1000 yr. Comparison of the results from the European and Asian regions is shown in Figure 4e. The authors connected the observed differences between the data sets with strong nondipole anomalies in Europe. The dipole field increased from its minimum in the vicinity of $\sim 5500 \mathrm{BC}$, reached its maximum in the vicinity of $\sim 1000 \mathrm{BC}$, and remained close to this maximum for almost 2000 yr. As can be seen from Figure 4e, the noticeable difference in European and Asian geomagnetic data during this maximum occurred during the time interval from $\sim 1000 \mathrm{BC}$ to $\sim \mathrm{AD} 50$, which includes the Sterno-Etrussia excursion. This difference indicates the non-dipolar character of the geomagnetic field.

So far, the evidence of the Sterno-Etrussia excursion has been found in magnetic properties of specimens of marine, lake, and continental sediments, as well as in the directions of magnetized mineral grains in oriented archaeological specimens from 15 widely distributed localities (Table 1). Not all references from Table 1 contain data of the geomagnetic field variation (remanent magnetization) during the Sterno-Etrussia geomagnetic excursion. Nonetheless, the available data covering mainly the European part of Russia, the Baltic and Barents Seas, and the Caucasus region are in favor of a $30-50 \%$ drop of the geomagnetic field during such an excursion. This effect should strengthen the fluxes of GCR in this period and, therefore, amplify the effects connected with an increase of the GCR fluxes.

At present, it is difficult to say exactly what was the reason for this excursion: whether it was a decrease of the dipole or the quadrupole component of the geomagnetic field. To establish this fact, additional investigations are needed in various regions of the world. However, in any case, regions of field drops will be over large areas and will significantly affect the integrated values of the GCR flux, having an influence on climatic changes. Another factor influencing the climate might be a shift in latitude of the geomagnetic pole during the excursion and, hence, a spatial movement of the GCR precipitation regions to low latitudes, to the Equator. According to Hagstrom et al. (2002), a virtual magnetic pole moved quickly from the New Land through Scandinavia to Greenland in 
2700-2340 BP. Therefore, it was situated $10-15^{\circ}$ south of its present location. In that period, the regions of intense GCR precipitation covered not only high latitudes but also middle latitudes and, therefore, might affect considerably the atmospheric circulation.

On the basis of paleomagnetic data, Raspopov et al. (2003) found that during this excursion, the virtual geomagnetic pole (VGP) path during 2800 to $2200 \mathrm{BP}$ moved from high to low latitudes in the longitude sector from $40^{\circ} \mathrm{E}$ to $30^{\circ} \mathrm{W}$. The excursion path reveals not only very rapid movement of the VGP during this time interval, but also a VGP excursion over a considerable distance. Figure 5 shows the virtual magnetic pole position during the excursion for 3 sites of the paleomagnetic investigations: Baltic Sea, Pichori (Caucasus), and West Siberia.

a)

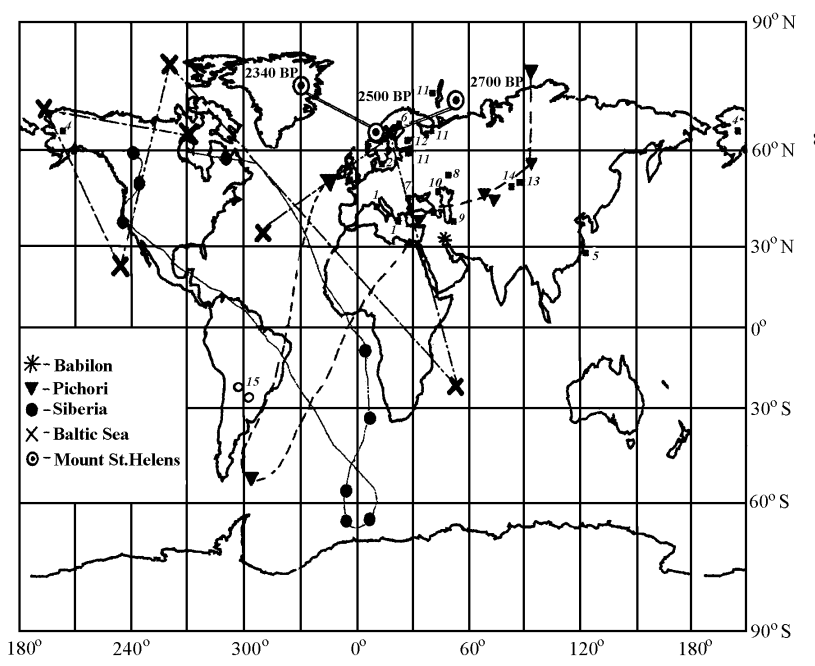

b)

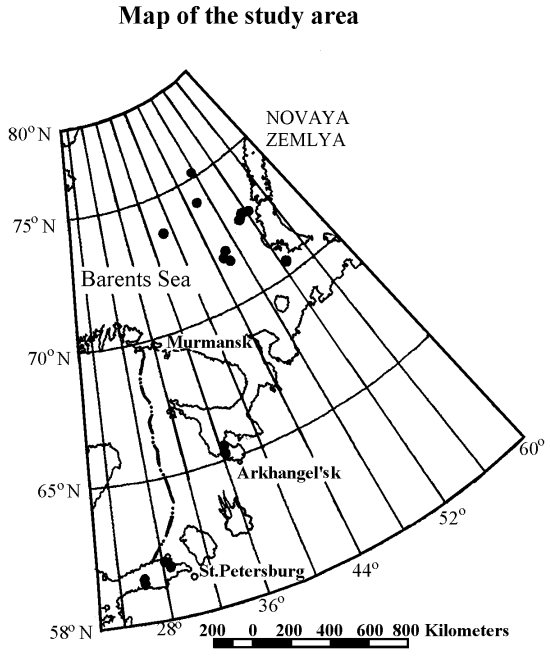

Figure 5 Map showing local sites (filled squares) of the discovered geomagnetic Sterno-Etrussia excursion and the virtual magnetic pole position during the excursion; Numbers 1-14 indicate the regions where the manifestations of the excursion were discovered. The virtual geomagnetic pole path is shown for the archaeological Pichori object (filled triangles), for continental sediments from Siberia (filled circles), and for the Baltic Sea sediments (crosses). The VGP path from $2700 \mathrm{BP}$ to $2340 \mathrm{BP}$ inferred from studies of volcanic sediments from the Mount St. Helens, Washington, is shown by open circles with a dot inside.

In all cases, movement of the VGP happened in the longitudinal interval from $40^{\circ} \mathrm{E}$ to $30^{\circ} \mathrm{W}$. Are there any experimental data confirming this shift of the geomagnetic pole? Apparently, yes. Historical chronicles suggest that optical atmospheric effects similar to the auroras occurred on the latitudes of Ancient Greece and Mesopotamia, that is $30-40^{\circ} \mathrm{N}$ (Brekke and Egeland 1983; Siscoe et al. 2002). The appearance of auroras supports movement of the geomagnetic pole (and, therefore, the regions of intense influence of CR) to middle and low latitudes. Thus, the development of geomagnetic excursion, promoting increase of the CR fluxes in middle and low latitudes, might noticeably change the structure of atmospheric circulation, as was earlier shown on the example of SPE. First of all, there should be an increase of zonal circulation (transfer of air in the east direction), as well as an increase of precipitation amount, which was actually observed in Europe in the considered interval.

Modern data indicate that variations in cosmic rays controlled by both solar activity and geomagnetic field affect the lower atmosphere and, hence, climate parameters. All these facts show that 
investigation of the events in the paleomagnetic data associated with inversions and excursions of the earth's magnetic field is of particular importance. During the reversal of the total magnetic field polarity, the magnetic moment decreases, allowing increased penetration of cosmic rays into the upper atmosphere. Global changes in the electromagnetic field of the earth result in sharp changes in the climate-forming factors in the atmosphere, such as temperatures, total pressure field, moisture circulation, intensity of air flows, and thunderstorm activity. Thus, geomagnetic excursions, which vary the configuration and value of the magnetic field, can affect climatic changes.

\section{CONCLUSION}

Sharp climate changes around $2700 \mathrm{BP}$ are well expressed and well dated in a number of different proxy data. Similar events occurred every $\sim 2400 \mathrm{yr}$, when the intensity of galactic cosmic rays was high. The analysis of paleoenvironmental and archaeological data around $2700 \mathrm{BP}$ supports the idea that external forcing has played a crucial role in sharp climate change during the Holocene. Comparison of fluctuations of the cosmic ray intensity with the detailed proxy record shows that the changing solar activity is a major factor in forcing climate. The sharp shift to cooler, wetter climatic conditions around $2700 \mathrm{BP}$ in the Northern Hemisphere has a parallel with the LIA, which was also related to reduced solar activity. Despite the evidence from the past, solar variability remains controversial as a source of climate change, since the underlying mechanism remains as a puzzle. Changes in solar activity estimated from the instrumental measurements are considered to be too small to cause climate variability.

At present, 3 possible mechanisms of links between solar variability and changes in climate are taken in consideration: 1) changes in total solar irradiance and its influence on the lower atmosphere; 2) changes in solar ultraviolet radiation, related ozone production, and the interaction with the stratosphere and troposphere; and 3) changes in cloud formation related to changes in cosmic ray intensity. It is particularly remarkable that cosmic rays, the flux of which is modulated by the solar wind and geomagnetic field strength, provide the sole source of ions, apart from terrestrial sources of radioisotopes. Solar modulation of cosmic ray intensity could provide an effective initial step by which an energetically weak solar signal (both irradiance and ultraviolet radiation changes are very small) is amplified into a significant climate forcing.

The analysis of paleomagnetic data shows that around $2700 \mathrm{BP}$, a short and pronounced excursion of the earth magnetic field took place. This Sterno-Etrussia excursion had caused a temporary sharp increase of cosmic ray flux, not only in the northern altitudes but also in the low and middle latitudes. The excursion was contemporaneous with a deep minimum of solar activity around $2700 \mathrm{BP}$. As a consequence, during the geomagnetic excursion, the zonal circulation and cloudiness increased and it was accompanied by cooling. Precipitation probably was strongly affected and the environmental conditions in the Northern Hemisphere were strongly influenced. The combined effect of external factors (solar activity decay, fast changes of the geomagnetic field, and related cosmic ray enhancement) around $2700 \mathrm{BP}$ triggered abrupt climate change. The available evidence points to an important role of changing cosmic ray intensities in climate change.

\section{ACKNOWLEDGEMENTS}

The research was supported by the Netherlands Organisation for Scientific Research (NWO project 047.009.005) and Russian Foundation for Basic Research (project 03-05-65063). 


\section{REFERENCES}

Abbott MB, Binford MW, Kelts KR. 1997. A $3500{ }^{14} \mathrm{C}$ yr high-resolution record of water-level changes in Lake Titicaca, Bolivia/Peru. Quaternary Research 47:16980.

Barber K, Langdon P. 2001.Testing the paleoclimatic signal from peat bogs - temperature or precipitation forcing? Abstracts, PAGES-PEPIII/ESF-HOLIVAR International Conference: Past Climate Variability Through Europe and Africa, ECRC/CERegE. p 58-9.

Barber KE, Zolitschka B, Tarasov P, Lotter A. Forthcoming. Atlantic to Urals - the Holocene climatic record of mid-latitude Europe. In: Battarbee RW, Gasse F, editors. Past Climate Variability Through Europe and Africa. Dordrecht: Kluwer.

Betancourt JL, Latorre C, Rech J, Quade J, Rylander KA. 2000. A 22,000-year record of monsoonal precipitation from northern Chile's Atacama Desert. Science 289:1542-6.

Bond G, Showers W, Cheseby M, Lotti R, Almasi P, deMenocal P, Priore P, Cullen H, Hajdas I, Bonani G. 1997. A pervasive millennial-scale cycle in North Atlantic Holocene and glacial climates. Science 278: 1257-66.

Bond GC, Kromer B, Beer J, Muscheler R, Evans MN, Showers W, Hoffmann S, Lotti R, Hajdas I, Bonani G. 2001. Persistent solar influence on North Atlantic climate during the Holocene. Science 294:2130-6.

Brekke A, Egeland A. 1983. The Northern Light. Berlin, Heidelberg: Springer-Verlag. $170 \mathrm{p}$.

Brook GA, Rafter MA, Railsback LB, Sheen S-W, Lundberg J. 1999. A high-resolution proxy record of rainfall and ENSO since AD 1550 from layering in stalagmites from Anjohibe Cave, Madagascar. The Holocene 9:695-705.

Bryant EA, Young RW, Price DM. 1992. Evidence for Pleistocene and Holocene raised marine deposits, Sandon Point, New South Wales. Australian Journal of Earth Sciences 39(4):481-93.

Burakov KS, Nachasova IE, Generalov AG. 1996. Record of geomagnetic field variations in the chemical remanent magnetization of sediments of the archaeological site Kazachka. Abstracts. Paleomagnetism and Magnetism of Rocks. Moscow: Institute of Earth Physics. p 15-8. In Russian.

Burlatskaya SP, Chelidze ZA. 1987. About change of the geomagnetic field in Georgia from 3rd millennium BC to 1st millennium AD. Physics of the Earth 9:102-7. In Russian.

Burlatskaya SP, Chelidze ZA. 1990. The changes of geomagnetic field in Georgia during the last 1500 years BC. Izvestiya Academii Nauk USSR, Physics of the Earth 7:84-93. In Russian.

Christoforou P, Hameed S. Solar cycle and the Pacific "centers of action." Geophysical Research Letters 24: 293-6.

Curtis JH, Hodell DA, Brenner M. 1996. Climate vari- ability on the Yucatan Peninsula (Mexico) during the past 3500 years, and implications for Maya cultural evolution. Quaternary Research 46(1):37-47.

Dansgaard W, Johnson SJ, Clausen HB, Dahl-Jensen D, Gundestrup NS, Hammer CU, Hvidberg CS, Steffensen JP, Sveinbjörnsdottir AE, Jouzel J, Bond G. 1993. Evidence for general instability of past climate from a 250-kyr ice-core record. Nature 364:218-20.

Denniston RF, González LA, Asmerom Y, Sharma RH, Reagan MK. 2000. Speleothem evidence for changes in Indian summer monsoon precipitation over the last 2300 years. Quaternary Research 53:196-202.

Denton GH, Karlen W. 1973. Holocene climatic variations - their pattern and possible cause. Quaternary Research 3:155-205.

Dergachev VA, Chistyakov VF. 1995. Cosmogenic radiocarbon and cyclical natural processes. Radiocarbon 37(3):417-24.

Dergachev VA, van Geel B, Zaitseva G, Alekseev A, Chugunov K, van der Plicht J, Possnert G, Raspopov O. 2000. The earliest records of Scythians in Eurasia and sharp climatic changes around 2700 BP. In: Paraske-Vopoulos KM, editor. Physics in Culture I. The Solid State Physics in the Study of Cultural Heritage. Athens: Aristotle University of Thessaloniki. p 208-16.

Dimitriev AA, Lomakina EY. 1977. Cloudiness and solar X-ray emission. In: Rakipova LR, editor. Solar Activity Effects in the Lower Atmosphere. Leningrad: Hydrometeoizdat. p 70-5. In Russian.

Eddy E. 1976. The Maunder Minimum. Science 192: 1189-202.

Eiriksson J, Knudsen KL, Rytter F. 2002. North Icelandic shelf sediments: Holocene and Lateglacial record of oceanographic events. 32nd International Arctic Workshop. 14-16 March 2002. Institute of Arctic and Alpine Research, University of Colorado, Boulder, Colorado, USA. Program and Abstracts. p 77-8.

Eremin VN, Shadrukhin AB, Molostovskyi EA. 1992. Holocene of north coast of Caspian Sea. Bulletin of Moscow Society of Nature 67(6):54-63. In Russian.

Esper J, Cook ER, Schweingruber FH. 2002. Low-frequency signals in long tree-ring chronologies for reconstructing past temperature variability. Science 295:2250-3.

Gnibidenko ZN, Volkova VS, Orlova LA. 2000. Climatolomagneto chronology and magnetism of Holocene deposits in upper Ob' region. In: Vaganov EA, Derevyanko AR, Zykin VS, Markin SV, editors. Problem Reconstruction of Climate and Environment of the Holocene and Pleistocene in Siberia. Novosibirsk: Nauka. p 110-5. In Russian.

Gracheva R, Sorokin A, Chichagova O, Tishkov A, Vanderbenghe J, Sulerzhitskyi L. 2002. Stages of paleoenvironmental change in the Upper Volga region in the Holocene. NWO-DUT-MGU-DGU Workshop Ho- 
locene Caspian Sea Level Change, 21-22 October 2002. Delft University of Technology, Department of Applied Earth Sciences. Abstracts. p 9-10.

Guskova EG, Raspopov OM, Piskarev AL, Dergachev VA, Mörner N-A. Forthcoming. The fine structure of the geomagnetic field for the last 30,000 year on the base of Barents Sea sediments. Geomagnetism and Aeronomy.

Gustafsson BG, Westman R. 2002. On the causes for salinity variations in the Baltic Sea during the last 8500 years. Paleoceanography 17(3):1040.

Fontugne M, Usselmann P, Lavallete D, Julien M, Hatté C. 1999. El Niño variability in the coastal desert of southern Peru during the mid-Holocene. Quaternary Research 52:171-9.

Hagstrom JT, Hoblitt RP, Gardner CA, Gray TE. 2002. Holocene geomagnetic secular variation recorded by volcanic deposits at Mount St. Helens, Washington. Bulletin of Volcanology 63:545-56.

Haigh JD. 1994. The role of stratospheric ozone in modulating the solar radiative forcing of climate. Nature 370:544-6.

Haigh JD. 1996. The impact of solar variability on climate. Science 272:981-4.

Johnsen SJ, Dahl-Jensen D, Gundestrup N, Steffensen JP, Clausen HB, Miller H, Masson-Delmotte V, Sveinbjornsdottir AE, White J. 2001. Oxygen isotope and paleotemperature records from six Greenland ice-core stations: Camp Century, Dye-3, GRIP, GISP2, Renland and NorthGRIP. Journal of Quaternary Science 16(4):299-307.

Karpychev JuA. 1994. The periodicity of the level of the Caspian Sea on the data of radiocarbon analysis of new Caspian sediments. Vodnye Resursy 21(4):41521. In Russian.

Kochegura VV. 1992. Use the Paleomagnetic Methods for Geological Mapping of Sea Shelf. St. Petersburg: VSEGEI. 144 p. In Russian.

Kochegura VV, Piskarev AL, Zhemchuzhnikov EG. 1999. Paleomagnetic study of the Holocene marine sediments in the Barents, White and Baltic Seas. Abstracts of the EGS Annual Meeting, The Hague, April 1999. p 134.

Kodama M, Kohmo T, Kanzawa H. 1992. Stratospheric sudden cooling after solar proton event over Syowa Station. Journal of Geomagnetism and Geoelectricity 44:361-6.

Kroonenberg SB, Abdurakhmanov GM, Badyukova EN, van der Borg K, Kasimov NS, Rychagov GI, Svitoch AA, Vonhof HB, Wesselingh FP. The 2600 BP and Little Ice Age highstands of the Caspian Sea. NWODUT-MGU-DGU Workshop Holocene Caspian Sea Level Change, 21-22 October 2002. Delft University of Technology, Department of Applied Earth Sciences. Abstracts. p 20.

Lamb HH. 1995. Climate, History and the Modern World. London: Methuen. 433 p.
Langdon PG, Barber KE, Hughes PDM. 2003. A 7500 year peat-based paleoclimatic reconstruction and evidence for an 1100-year cyclicity in mire surface wetness from Temple Hill Moss, Pentland Hills, southeast Scotland. Quaternary Science Reviews 22:259-74.

Levitan MA, Duplessy J-C, Khusid TA, Beljaev NA, Bourtman MV. 1999. Holocene sediments of the Southern Novaja Zemlya Trough (the Pechora Sea) and Brunhes history. IMAGES, P.P. Shirshov Institute of Oceanology RAS, Moscow. p 11-2.

Luckman BH, Holdsworth G, Osborn GD. 1993. Neoglacial glacial fluctuations on the Canadian Rockies. Quaternary Research 39:144-53.

Maisch M, Wipf A, Denneller B, Battaglia J, Benz C. 1999. Die Gletscher der Schweizer Alpen. Gletscherhochstand 1850, Aktuelle Vergletscherung, Gletscherschwund-Szenarien. Zürich: Vdf. 373 p.

Magny M. 1993a. Solar influences on Holocene climatic changes illustrated by correlations between past lakelevel fluctuations and the atmospheric ${ }^{14} \mathrm{C}$ record. Quaternary Research 40:1-9.

Magny M. 1993b. Un cadre climatique pour les habitats lacustres préhistoriques? Comptes Rendus de l'Academie des Sciences Paris 316:1619-25.

Magny M. 1995. Successive oceanic and solar forcing indicated by Younger Dryas and early Holocene climatic oscillations in the Jura. Quaternary Research 43:279-85.

Magny M.1999. Lake level fluctuations in the Jura and French subalpine regions associated with ice-rafting in the North Atlantic and variations in the polar atmospheric circulation. Quaternaire 10:61-4.

Magny M. 2004. Holocene climate variability as reflected by mid-European lake-level fluctuations and its probable impact on prehistoric human settlements. Quaternary International 113:65-79.

Maley J, Brenac P. 1998. Vegetation dynamics, paleoenvironments and climatic changes in the forest of western Cameroon during the last 28,000 years BP. Review of Paleobotany and Palynology 99:157-87.

Mann ME. 2000. Climate chance-lessons for a new millennium. Science 289:253-54.

Marsh N, Svensmark H. 2000. Cosmic rays, clouds, and climate. Space Science Reviews 94:215-30.

McElhinny MW, Senenayake WE. 1982. Variations in the geomagnetic dipole- 1 . The past 50,000 years. Journal Geomagnetism and Geoelectricity 34:39-51.

McFadden LD, McAuliffe JR. 1997. Lithologically influenced geomorphic responses to Holocene climate changes in the southern Colorado Plateau, Arizona: a soil-geomorphic and ecological perspective. Geomorphology 19:303-32.

Moqing Z, Zongshi G. 1987. Discussion on polarity events of Brunhes normal polarity epoch in the Yellow Sea. Marine Geology and Quaternary Geology 7(4): 49-56.

Morinaga H, Morinaga KS, Yaskowa H. 1987. Paleo- 
magnetic implication on climatic changes and evidence for excursions recorded in a sediment core from Harding Lake, Alaska. Journal of Geomagnetism and Geoelectricity 39(4):229-41.

Mörner N-A, Sylvan CA. 1989. Detailed paleomagnetic record for the last 6300 years from varved lake deposits in northern Sweden. In: Lowes FJ, editor. Geomagnetism and Paleomagnetism, NATO ASI series, Series C, Mathematical and Physical Sciences. p 63-70.

Murdmaa IA, Ivanova EV. 1999. After Ice Age sedimentation history in shelf regions of Barents Sea. Lithology and Minerals (Litologiya i Poleznye Iskopaemie) 6:576-95. In Russian.

Nachasova IE, Burakov KS, Kvirikadze MB. 1986. Paleointensity of geomagnetic field in Georgia in the first millennium BC. Geomagnetism and Aeronomy 23(2): 356-8. In Russian.

Nachasova IE, Burakov KS. 2002. Geomagnetic field strength in the 6th century BC-2nd century AD. Geomagnetism and Aeronomy 42(2):272-5.

Noel M, Tarling DH. 1975. The Laschamps geomagnetic event. Nature 253:705-7.

O'Brien SR, Mayewski PA, Meeker LD, Meese DA, Twickler MS, Whitlow SI. 1995. Complexity of Holocene climate as reconstructed from a Greenland ice core. Science 270:1962-4

Pallé Bagó E, Butler CJ. 2000. The influence of cosmic rays on terrestrial clouds and global warming. Astronomy \& Geophysics 40(4):418-22.

Polyak VJ, Asmerom Y. 2001. Late Holocene climate and cultural changes in the southwestern United States. Science 294:148-51.

Pudovkin MI, Babushkina SV. 1992a. Atmospheric transparency variations associated with geomagnetic disturbances. Journal of Atmospheric and Terrestrial Physics 54:1135-8.

Pudovkin MI, Babushkina SV. 1992b. Influence of solar flares and disturbances of the interplanetary medium on the atmospheric circulation. Journal of Atmospheric and Terrestrial Physics 54:841-6.

Pudovkin MI, Raspopov OM. 1992. The mechanism of action of solar activity on the state of lower atmosphere and meteorological parameters. Geomagnetism and Aeronomy 32:593-608. English edition.

Pudovkin MI, Veretenenko SV. 1995. Cloudiness decreases associated with Forbush decreases of galactic cosmic rays. Journal of Atmospheric and SolarTerrestrial Physics 75:1349-56.

Ransom CJ. 1973. Magnetism and archaeology. Nature 242:218-9.

Renssen H, van Geel B, van der Plicht J, Magny M. 2000. Reduced solar activity as a trigger for the start of the Younger Dryas? Quaternary International 68-71: 373-83.

Raspopov O, Shumilov O, Kochegura V, Dergachev V, van Geel B, van der Plicht J, Renssen H, Maley J. 1998. Dendrochronological and other proxy evidence for climatic cooling around $2700 \mathrm{BP}$ and its heliogeophysical forcing. In: Stravinskiene V, Juknys R, editors. Proceedings of the International Conference "Dendrochronology and Environmental Trends." 1721 June 1998, Kaynas, Lithuania, Vytautas Magnus University, Kaunas. p 113-23.

Raspopov OM, Shumilov OI, Dergachev VA, van Geel B, Mörner N-A, van der Plicht J, Renssen H. 2000. Abrupt climate change around 2700-2800 years BP as example of existence of 2400 year periodicity in solar activity and solar variability. Proceedings of 1st Solar \& Space Weather Euro-Conference, "The Solar Cycle and Terrestrial Climate," Santa Cruz de Tenerife, Spain, 25-29 September 2000 (ESA SP-463, December 2000). p 513-16.

Raspopov Oleg M, Dergachev Valentin A, Goos'kova Elena G. 2003. Ezekiel's vision: visual evidence of Sterno-Etrussia geomagnetic excursion? EOS, Transactions, American Geophysical Union 84(9) March: 77.

Riedinger M, Steinitz-Kannan M, Last W, Brenne M. 2002. A $\sim 6100{ }^{14} \mathrm{C}$ record of El Niño activity from the Galapagos Islands. Journal of Paleolimnology 27:17.

Rothlisberger F. 1986. 10,000 Jahre Gletscher-geschichte der Erde. Aarau: Verlag Sauerlande. 384 p.

Rychagov GI. 1997. Holocene oscillations of the Caspian Sea, and forecasts based on paleogeographical reconstructions. Quaternary International 41-42:167-72.

Saarinen TJ. 1994. Paleomagnetic study of the Holocene sediments of Lake Päijänne (Central Finland) and Lake Paanjarvi (North-West Russia). Bulletin of the Geological-Survey of Finland $\mathrm{nr} 376.88 \mathrm{p}$.

Sandweiss D H, Maasch KA, Burger RL, Richardson III JB, Rollins HB, Clement A. 2001. Variation in Holocene El Niño frequencies: climate records and cultural consequences in ancient Peru. Geology 29(7): 603-6.

Sauchyn MA, Sauchyn DJ. 1991. A continuous record of Holocene pollen from Harris Lake, southwestern Saskatchewan, Canada. Palaeogeography, Palaeoclimatology, Palaeoecology 88:13-23.

Schilman B, Bar-Matthews M, Almogi-Labin A, Luz B. 2001. Global climate instability reflected by eastern Mediterranean marine records during the Late Holocene. Palaeogeography, Palaeoclimatology, Palaeoecology 176(1-4):157-76.

Scott L, Lee-Thorp JA. Forthcoming. Holocene climatic trends and rhythms in southern Africa. In: Battarbee RW, Gasse F, editors. Past Climate Variability Through Europe and Africa. Dordrecht: Kluwer.

Shumilov OI, Henriksen K, Raspopov OM, Kasatkina EA. 1992. Arctic ozone abundance and solar proton events. Geophysical Research Letters 19:1647-50.

Shumilov OI, Kasatkina EA, Henriksen K, Raspopov OM. 1995. Ozone "mini-holes" initiated by energetic solar protons. Journal of Atmospheric and Terrestrial 
Physics 57:665-71.

Siscoe GL, Silverman SM, Siebert. 2002. Ezekiel and the northern lights: biblical aurora seems plausible. EOS Transaction, American Geophysical Union 83(16): 173, 179.

Speranza A, van Geel B, van der Plicht J. 2002. Evidence for solar forcing of climate change at ca. $850 \mathrm{cal} \mathrm{BC}$ from a Czech peat sequence. Global and Planetary Change 35:51-65.

Stephenson LAE, Scourfield MWJ. 1992. Ozone depletion over the polar cap caused by solar protons Geophysical Research Letters 19:2425-8.

Stozhkov YI, Zullo J, Martin Jr IM, Pellegrino GQ, Pinto HS, Bezerra PC, Bazilevskaya GA, Machmutov VS, Svirzevskii NS, Turtelli Jr A. 1995. Rainfalls during great forbush-decreases Nuovo Cimento C 18:335-41.

Stötter J, Wastl M, Caseldine C, Häberle T. 1999. Holocene paleoclimatic reconstruction in Northern Iceland: approaches and results. Quaternary Science Reviews 18:457-74.

Stuiver M, Reimer PJ, Braziunas TF. 1998. High-precision radiocarbon age calibration for terrestrial and marine samples. Radiocarbon 40(3):1127-52.

Suleimanova FI. 1987. The fine structure of the geomagnetic field in Quaternary deposits on pre-Ural region. In: Sidorov A, editor. Paleomagnetism in Geology. Magadan: SVKNIIDVNTS. p 5-14. In Russian.

Svensmark H, Friis-Christensen E. 1997. Variation in cosmic ray flux and global cloud coverage - a missing link in solar-climate relationships? Journal of Atmospheric and Solar-Terrestrial Physics 59:1225-32.

Tinner W, Lotter A, Ammann B, Conedera M, Hubschmid P, van Leeuwen JFN, Wehrli M. 2003. Climatic change and contemporaneous land-use phases north and south of the Alps 2300 BC to AD 800 . Quaternary Science Reviews 22:1447-60.

Tinsley BA, Dean GW. 1991. Apparent tropospheric response to $\mathrm{MeV}-\mathrm{GeV}$ particle flux variations: a connection via the solar wind, atmospheric electricity and cloud microphysics. Journal of Geophysical Research 96:22,283-96.

Tinsley BA. 1988. The solar cycle and the QBO influence on the latitude of storm tracks in the North Atlantic. Geophysical Research Letters 15:409-12.

Tretjak AN, Vigilyanskaya LI, Makarenko VN, Dudkin VP. 1989. Fine Structure of the Geomagnetic Field in the Late Cenozoic. Kiev: Naukova Dumka. 156 p. In Russian.

Trubikhin VM, Bagin VI, Gender TS, Nechaeva TB, Fein AG. 1991. About the reality of the paleomagnetic record on takyrs. Abstracts of the IV All-State Meeting for Geomagnetism, Moscow, Part II. p 49-50. In Russian.

van Geel B, Buurman J, Waterbolk HT. 1996. Archaeological and paleoecological indications of an abrupt climate change in the Netherlands, and evidence for climatological teleconnections around $2650 \mathrm{BP}$.
Journal of Quaternary Science 11(6):451-60.

van Geel B, van der Plicht J, Kilian MR, Klaver ER, Kouwenberg HM, Renssen H, Reynaud-Farrera I, Waterbolk HT. 1998a. The sharp rise of $\Delta{ }^{14} \mathrm{C}$ ca. $800 \mathrm{cal} \mathrm{BC:}$ possible causes, related climatic teleconnections and the impact on human environments. Radiocarbon 40(1):535-50.

van Geel B, Raspopov OM, van der Plicht J, Renssen H. 1998b. Solar forcing of abrupt climate change around 850 calendar years BC. In: Peiser BJ, Palmer T, Bailey ME, editors. Natural Catastrophes During Bronze Age Civilizations. BAR International Series 728:1628.

van Geel B, Raspopov OM, Renssen H, van der Plicht J, Dergachev VA, Meijer HAJ. 1999. The role of solar forcing upon climate change. Quaternary Science Reviews 18(3):331-8.

van Geel B, Renssen H. 1998. Abrupt climate change around $2650 \mathrm{BP}$ in northwest Europe: evidence for climatic teleconnections and a tentative explanation. In: Issar AS, Brown N, editors. Water, Environment and Society in Times of Climatic Change. Dordrecht: Kluwer. p 21-41.

Vasiliev SS, Dergachev VA, Chistyakov VF. 1997. 2400 -year cycle detection in natural radiocarbon level in the atmosphere and the sensitivity of human behavior to the large-scale climatic changes. Radiocarbon and Archaeology, St. Petersburg, Institute of the History of Material Culture nr 2:13-35. In Russian.

Vasiliev SS, Dergachev VA. 2002. The $\sim 2400$-year cycle in atmospheric radiocarbon concentration: bispectrum of ${ }^{14} \mathrm{C}$ data over the last 8000 years. Annales Geophysicae 20:115-20.

Veretenenko SV, Pudovkin MI. 1993. Effects of cosmic ray variations on atmospheric circulation. Geomagnetism and Aeronomy 33:35-49. In Russian.

Waple AM, Mann ME, Bradly RS. 2002. Long-term patterns of solar irradiance forcing in model experiments and proxy based surface temperature reconstruction. Climate Dynamics 18:563-78.

Wastl M, Stötter J, Caseldine C. 2001. Reconstruction of Holocene variations of the upper limit of tree or shrub birch growth in northern Iceland based on evidence from Vesturárdalur-Skíðadalur, Tröllaskagi. Arctic, Antarctic, and Alpine Research 33(2):191-203.

Wilkins DE, Currey DR. 1997. Timing and extent of late Quaternary paleolakes in the Trans-Pecos closed basin, west Texas and southcentral New Mexico. Quaternary Research 47:306-15.

Wilson SE, Smol JP, Sauchyn DJ. 1997. A Holocene paleosalinity diatom record from southwestern Saskatchewan: Harris Lake revisited. Journal of Paleolimnology 17(1):23-31.

Yang S, Odah H, Shaw J. 2000. Variations in the geomagnetic dipole moment over the last 12,000 years. Geophysical Journal of Interior 140:158-62. 